Branko ILIČ, Dana MESNER ANDOLŠEK*

\title{
FIRM STRATEGY AND INNOVATION DYNAMICS: A CONCEPTUAL MODEL OF INNOVATION COMPETITION
}

\begin{abstract}
Firms of different business strategy types reveal different behavioural patterns in their innovation and business performance while facing various difficulties as they seek to adapt to a turbulent competitive environment. Accordingly, we want to make progress by using the dynamic view, which follows the Schumpeterian perspective of firm behaviour through innovation (business) strategy. We advocate a dynamic approach to the strategic and behavioural patterns influencing business performance that is appropriate for small and mediumsized firms as well as giant corporations in highly competitive industries and catching-up economies. Thus, by combining different theoretical approaches we develop an alternative conceptual 'cost-advantage leader-follower' (CALF) model of innovation for when firms are developing cost-cutting process inventions.

Keywords: Business strategy, Innovation strategy, Innovation, Cost-advantage leader-follower model, catching-up economies
\end{abstract}

\section{Introduction}

Today, the global economy is accelerated by entrepreneurship and innovation. Researchers regard entrepreneurship as "processes to pursue opportunity without regard to resources currently controlled" (Stevenson and Jarillo, 1990) and as "organizational behaviour based on strategic posture for pursuing opportunities" (Covin and Slevin, 1991; Lumpkin and Dess, 1996; Zahra, 1993). The identification and exploitation of promising business opportunities are key entrepreneurial processes (Shane and Venkataraman, 2000).

For entrepreneurs and industries as well, the ability to find attractive opportunities and marshal internal and external resources are critical factors for ensuring higher performance and long-term survival. Historically, ventures and firms in advanced nations have been recognised as the sources

* Branko Ilič, PhD, Assistant Professor, Faculty of Social Sciences, University of Ljubljana, Slovenia, Dana Mesner Andolšek, PhD, Associate Professor, Faculty of Social Sciences, University of Ljubljana, Slovenia. 
of innovation that change technological frontiers and the competitive landscape (Schumpeter, 1934/2004; Utterback, 1994). Ventures and firms in developing countries also have a disproportionate importance on domestic job creation and economic development. Despite the significant role played by ventures, relatively little is known about the competitive strategy and behaviour patterns of ventures and firms in developing countries (Park and Bae, 2004).

Today, the strategic management field is faced with many new challenges that stem from the continuing changes in the dynamics of the environment in which organisations operate through the mutually dependent strategic actions of rival firms. The purposes of this study are to: (i) develop an integrative framework for venture and firm strategy; and (ii) show situations in which it can be appropriate, such as in catching-up economies and developing countries.

First, we briefly introduce and explain the framework and strategic types. We then explore an important dimension used in the framework, namely, the level of technological capability (or innovations) which firms develop to introduce new products and processes. Technological capability is regarded as one of the most important factors in the performance of new ventures and firms (Adler, 1989; Covin et al., 1999; Porter, 1983; Zahra, 1996; Zahra and Bogner, 1999). Innovators generate new technological knowledge and make their technological design of products and processes widely accepted by industry standards or dominant designs. In contrast, imitators follow technological trajectories and improve existing products initiated by innovators (Utterback, 1994). However, the traditional categorising of a firm as either innovator or imitator does not provide the complete background of the dynamic situation latecomers face. The businesses opportunities opened for these late arrivals are diverse. In many cases, they have exhibited dynamic growth patterns while faced with the challenge of the catching-up process (Cho et al., 1998). Especially in catching-up economies and developing countries, firms must respond to many extra competitive pressures, yet it is impossible to know ex ante how much will be gained from competition in relation to other strategic approaches.

In the dynamic approach we develop in this text, we follow the Schumpeterian perspective of competitive entrepreneurial activity through innovative strategy. In order to gain insight into how firms compete, we focus on further analysing the strategy, thereby also relying on Zahra and Bogner's (1999) concept of firm "technology strategy". The existing analytical concepts and tools allow for the separation of three different strategies (Porter, 1985): the strategy of differentiation, the cost strategy, and the specialisation strategy. In addition, a fourth group of 'firms that are stuck in the middle' is possible, i.e. those wanting to use more than one strategy, finding 
themselves 'in the middle', thus being unable to implement any of the strategies. In catching-up economies, firms have several strategic options derived from these three generic strategies.

The purpose of this article is to better understand the market and political factors that promote or inhibit the growth of firms with innovative business strategies. Our fundamental research question is whether (and to which extent, at least theoretically) a dynamic model of innovation competition and competitive advantage can be formed, hence being distant from existing, merely static models (e.g. Covin and Slevin, 1991; Etro, 2004) Accordingly, our aim is - unlike Etro (2004) and considering some similar recent studies (e.g. Covin and Slevin, 1999; Kessler and Chakrabarti, 1996; Baumol, 2002; Beneito et al., 2014 etc) - to introduce an alternative, conceptual 'CALF model' based on proper innovation and technology strategy formation, and suitable for the competitive paradigm of patents which is more relevant for the conditions of intensive innovation competition between firms and industries than the traditional monopoly 'doctrine' of patents.

Using compilation and triangulation, i.e. a combination of abstraction, descriptive and causal-non-experimental method, classification, literature comparison, theoretical as well as interdisciplinary approaches (linking

138 management, entrepreneurship, economics), we study the comprehension of strategy and introduce the theoretical approach of a dynamic firm that pursues a competitive advantage. Another focus is on the business environment described as 'the strategic triangle' of industry-market-firm, determined by the macro environment (Ohmae, 1982) and internal dimensions of the firm as well (Dagnino and Rocco, 2009; Gandellini et al., 2012).

\section{Catching-up economies, developing countries and managerial practices}

Economic development is important with respect to innovation because it creates demand for innovation and facilitates its diffusion. The collapse of socialism, combined with the transition from a centrally-planned and centrally-managed economy to a market-driven one, with escalating inflation and novel forms of competition, held significant repercussions for the basic fabric and nature of organisations, their management and their employees (see, for example, Stanojević, 2006). Technological developments play a crucial role in innovation while social issues (i.e. institutional and cultural) create the preconditions for technological changes to be adopted (Lundvall, 1992). It may be argued that it is like a double-loop system, according to the concept of learning introduced by Argyris and Schön (1978), while analysing factors that affect innovation in path-dependent countries such as countries in Eastern and Central Europe. 
Past dependency is included in the framework of developments in various areas and provides an overview of the main trends during the transformational changes seen in Eastern and Central Europe over the last two decades. This perspective has led to the analysis of various behaviour patterns from the viewpoint of the role and consequences of path dependency. In Eastern and Central Europe, path dependency derives from various sources (Vadi and Lepisk, 2012). Meanwhile, the historical and political dimensions explain behavioural issues.

Martin (2008) uses business systems theory to analyse post-socialist Central and Eastern Europe. He distinguishes five models of post-socialist capitalism - liberal market, coordinated market, heterarchy, neo-colonial and comparative business systems, thereby identifying four critical features of post socialist transformation: asset ownership, capital accumulation, access to local, national and international production systems, and the degree of differentiation between the state and the economy.

Managerial behaviour creates the framework for processes and activities, while also shaping their direction, especially in the context of change. It is a widely shared assumption that strategic management and leadership style and behaviour are significant with respect to innovation (Woodman et al., 1993). Management practices can thus either facilitate or create a barrier to innovation, and this can be examined from this perspective. Accession to the European Union marks the period when management practices have developed within a market economy and a democratic society. The focus of firms on the local context does not imply innovativeness as much as the global perspective does, and it may thus be concluded that managers probably do not see the need for innovation when the firm is oriented to the local market compared to when the firm is oriented to the global market. This means we must dismantle the concept of strategy and introduce some more detailed categories in order to achieve our objective. This requirement arises when we ask whether firms that pursue the strategy of either differentiation, cost or specialisation are really competing in the same way. Of course, the answer is negative (Gimbert, 2011).

\section{Innovation: initial theoretical insight and typology}

Innovation may be understood as one of the mechanisms for building a firm's competitiveness or competitive advantage. The developmental economist Schumpeter (1939, 1951; Mathews, 2002) defined innovation as an economic change that is the result of entrepreneurship and also implying a change in the production function. According to Schumpeter (1951), many forms of innovation are possible, such as the following: new product, new production method, new market place, new raw material source and new 
form of organising production (i.e. organisational structure). Innovation

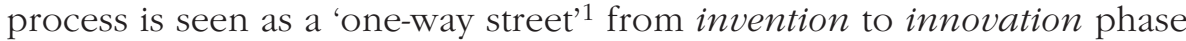
and to diffusion, i.e. spreading innovation across firms, industries and economies as well. Invention thereby means each creative idea or achievement while innovation refers to only that invention which can be commercialised. Although invention is an ongoing process, innovation arises sporadically as a result of a 'creative destruction' process driven by the dynamic innovation competition that forces firms to continuously innovate (Ilič and Pretnar, 2004). Taking this into account, our starting point is to conceptualise, compare and classify various strategies that define business innovation.

Many different definitions and classifications of innovations are possible. Innovation can be defined as the first use of an invention or science and technology for commercial means. It can broadly be defined as an idea, practice or material artefact perceived to be new from the user's or customer's point of view; it is the successful implementation of innovative ideas in an organisation (Dodgson and Gann, 2010: 14; see also Hurley and Hult, 1998). Similarly, Afuah (2003) states innovation as the use of new knowledge offering new products and services demanded by customers; innovation is thus invention and commercialisation simultaneously. Innovation 140 process can be defined as the generation, acceptance and implementation of new ideas, processes, products and services whereas innovativeness refers to organisational openness to new ideas from the organisational culture perspective (Hurley and Hult, 1998: 44). In addition, innovation cannot be separated from the strategic and competitive context of a firm (Afuah, 2003: 13) while accelerating and promoting R\&D. Thereby, the incentive to invent and innovate refers to different external (i.e. business environment, market structure) as well as internal factors (i.e. firm size, organisational structure, rewards system etc.), which also affect individual motivation and level of organisational innovation (Armstrong, 2006; Herzberg, 1987; Gagné and Deci, 2005: 336, 343; Ilič and Pretnar, 2004). Individual innovativeness should at least to some extent even depend on employees' family characteristics, forming 'familyness', i.e. a specific firm resource which should enable long-run survival and foster innovation (Habbershon and Williams, 1999).

Innovation can be of either the technical or non-technical type. Following Stoneman (1987), technical innovations are typically divided into product innovations (new products creating new demand) and process innovations (i.e. new cost-cutting processes). Each can be either a radical innovation implying discontinuities in technology and product development or an

1 Alternatively, an interactive innovation process is also possible, mutually linking all innovation phases (via feedback loops), firm researchers, business partners and government institutions promoting innovation as well. 
incremental innovation entailing sequences of gradual changes in small steps without discontinuity. Non-technical innovations, also named administrative or organisational innovations, refer to new organisational forms or the mutual interaction of technical (or corporate) and administrative innovations, with both generating synergetic effects for organisational performance (Han et al., 1998; Hellriegel et al., 1999; Teece, 1990).

\section{Comprehension of Business Strategies}

\section{Different Perspectives on Strategy}

In the literature, one finds different perspectives on strategy, i.e. the competitive perspective (Porter, 1980; Barney, 1986; Williamson, 1975, 1985; Borden, 1964) and an alternative strategic perspective, which has expanded in response to the competitive perspective and stresses the development and nurturing of "cooperative advantages" (Contractor and Lorange, 1988; Håkansson and Ostberg, 1975). Hybrid behaviour that contains both competition and cooperation, understood as "coopetition", may be indicated as the third perspective (Brandenburger and Nalebuff, 1996; Lado et al., 1997; Gnyawali and Madhavan, 2001).

The competitive perspective (Porter, 1980; Barney, 1986; Williamson, 1975, 1985; Borden, 1964) anticipates that the dependence of the firm, both vertically and horizontally, depends on a 'Smithsonian' search of individual interests. The allegory of the firm is thus "an island in a sea of competitive relations" (Richardson, 1972). As for the horizontal relationships, the competitive perspective emphasises the search for profit levels above normal levels, either when the firm reaches a position of advantage in the industry (Porter, 1985) or when it uses distinct competencies and resources (Wernerfelt, 1995; Hamel et al., 1989; Prahalad and Hamel, 1990) that enable the production of a superior product with regard to those of the competition. This perspective stresses rent-seeking, which is above the strategies of creating value and bringing in above-normal economic returns (i.e. extra profits). In a competitive setting, a new firm is forced to build a 'technology strategy', defined as the sum of the firm's choices on how to develop and exploit its technological resources, affecting the venture's performance and survival. Its technology strategy depends on the extent of new product or process radicality, the intensity of product upgrades, the R\&D spending level, use of external sources (e.g. strategic alliances, licensing agreements etc.) as well as on copyrights and other means to ensure intellectual capital protection (Zahra and Bogner, 1999: 139; Beneito et al., 2014: 286-287).

As for the vertical dependencies, the competitive perspective highlights the search for value appropriation in economic exchanges. Deriving from 
neoclassical economic theory, the competitive perspective assumes that economic exchange is a separate act or event at which the previous value, initially created by firms, is then split between competing firms based on the principle of allocative efficiency. Irrespective of the type of dependency and specific research in the field of management, the competitive perspective has a unified theoretical framework which can be set out.

The creation of economic value appears in a business where interactions between firms influence the distribution of value in both the firm's vertical and horizontal dependency. The competitive success and appropriation of the value of one firm mean the defeat and loss of value of another firm. It is a game where the entrepreneurial dependency is based on a zero-sum game. In the business world, in which each dependency forms part of the zero-sum game, all firms involved in the game always hold opposing interests.

\section{Competitive Advantage and Strategy}

All firms in any industry have some competitive advantage. A firm cannot survive without one (Gandellini et al., 2012). This is a necessary condition in

142 both the short and long run. The firm should protect its competitive advantage; if not, other firms will imitate it, thus seeing the firm lose its former advantage over its competitors. This is also the starting point for developing the dynamic CALF model that is introduced below. Note that competitive advantage is not an absolute but a relative concept: this means that it is not enough for the firm to be good, it must be better. The firm's management must constantly be on the lookout to see if the firm might be coming to the end of the cycle of its competitive advantage; it must also be in a state whereby, when this happens, it already has a new competitive advantage prepared, one without competition.

For our purpose, we need to focus more closely on the industry level, not so much a contextual macro-analysis because it is easier to observe the details of the business environment and its situation in relation to firms and competition in catching-up economies and firms' strategic behaviour or performance, in turn making it easier to explain why firms achieve profits. When ventures and firms in a developing country grow through a strategic change in the internationalisation process, research has established that creative imitation is very important as a stepping-stone and a milestone for gaining a sustainable competitive advantage (Park and Bae, 2004). Three factors were used by Park and Bae (ibid.) to classify new venture strategies - technological capability (follower vs. pioneer), product-market maturity (existing vs. emerging), and target market (local vs. global market) and showed that a two-step growth pattern - (i) migration to creative imitation 
in the local market, and (ii) transition from creative imitation to becoming a global player in the global market - is the most reasonable growth strategy for becoming a global venture. They observed two different new venture growth patterns: "growth through strategic replication" and "growth through strategic change". Growth patterns and the speed of change of successful new ventures vary according to: (i) the initial conditions firms face at the time of being founded; (ii) entrepreneurs' characteristics and management abilities; and (iii) a technology strategy to develop and accumulate technological capability through innovations.

\section{Firm strategy and innovation dynamics: conceptual framework and model formation}

\section{Innovation and business strategy}

Business strategy can be defined as "the pattern in the stream of decisions and activities that characterises the match an organisation achieves with its environment and that is determinant for the attainment of its goals" (Håkansson and Snehota, 2006: 258). Innovation strategy, on the other hand, "designates to what degree and in what way a firm uses innovation to perform its business strategy and to develop its performance" (Akman and Yilmaz, 2008: 73). Innovation strategy can thus be understood as a part/derivation or even as a type of business strategy, built into the business model since innovation is only one of several possible firm choices or actions available to accomplish its specific business goals (for more details, see Teece, 2010). The simplified conceptual relationship between the two is depicted in Figure 1.

Figure 1: CONCEPTUAL RELATIONSHIP BETWEEN BUSINESS AND INNOVATION STRATEGY

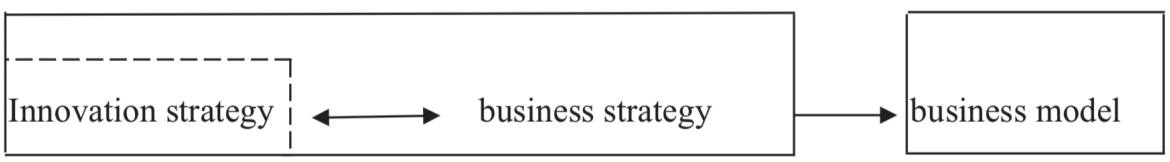

Source: own analysis.

Moreover, in the literature some authors classified business strategy from the innovation viewpoint, e.g. Shane and Venkatraman's (2000) six characteristics of a competitive strategy, conceptualising the dimensions of an innovation strategy as a basis. These are the following (see Akman and Yilmaz, 2008: 78; compare with the prospector, defender, analyser and reactor business strategy types in Miles et al., 1978): 
1. Aggressiveness, emphasising a combative posture in exploiting market opportunities, and relating to a firm's advances to become the first-mover in the market place, to develop radical innovations before competitors even at the expense of profitability and to give priority to innovation projects that involve high levels of risk and returns.

2. Analysis relates to the firm's ability to monitor and understand the external environment. It provides information to the firm about events and trends in its environment and assists it in recognising innovative opportunities. This innovation strategy type is very critical for firms to develop and commercialise successful innovations.

3. Defensiveness concerns the firm's need to defend its current position in the market place. Thus, in stable markets firms usually focus on current customer needs, shift the competitive emphasis to production and distribution efficiencies and to incremental product and process innovations.

4. Futurity refers to innovation opportunities based on the determination of future changes and developments in the environment, as well as an estimation of future market needs. It helps the firm make long-term innovation plans, also by anticipating future innovation opportunities.

5. Proactiveness means seeking new opportunities created by changes and developments in the environment, establishing new opportunities, and making innovations by exploiting these opportunities. Proactive firms support radical rather than incremental innovations.

6. Riskiness is a critical parameter in various resource allocation decisions as well as the choice of new products since innovation is inherently risky. It encourages behaviour concerned with market opportunity, i.e. seeking and transforming opportunities into innovative products and processes.

While taking the innovation (re)actions of competing firms into account, innovation strategies can first be divided into two broad groups (Freeman and Soete, 1997):

a. Offensive, proactive innovation strategies, applied by firms (i.e. innovation leaders) wishing to gain technological leadership or competitive advantage by introducing new products or processes based on own R\&D in order to create a leading market position, increase market share and realise post-innovation monopoly profits (e.g. 'the winner-takes-all' position in a patent race).

b. Defensive, reactive innovation strategies taken by other rival firms (i.e. innovation followers) which have to follow innovation leaders with both lagged own R\&D and imitation in order to survive and maintain their competitiveness and market share; in other words, taking a 'restingon-one's-laurels' position, as typical for defensive oligopolies waiting 
until innovation created by an innovation leader is introduced to the market and R\&D risk is resolved (Afuah, 2003: 126-127). The extent of R\&D delay thereby depends on the level of market rivalry. The greater the latter, the smaller the former, all else equal, thus defining the intensity of innovation competition. According Freeman and Soete (1997), other innovation strategy types can also be defined, as described below (Afuah, 2003).

c. Imitation strategy: taken by defensive innovators trying to obtain a competitive advantage over the first innovating firm by improving its innovation, e.g. through industrial design, minor technical improvements, product varieties, an incremental process and product innovation etc. This innovation strategy implies slowly following when already cheap and testable new knowledge exists to be a (costless) input for the imitator's own R\&D, with the latter resulting in competitive innovation through imitation. $^{2}$

d. Dependent strategy: applied when a firm faced with rival innovation accepts a subordinate role (functioning as a competitor's subcontractor or satellite) with respect to stronger firms without introducing or imitating technical changes, having an incentive to invent their own new products and own R\&D capacity. This strategy type is neither offensive nor defensive in nature.

e. Opportunistic strategy: enabling a firm to obtain a new market position or find a specific market niche for products and services required by niche customers. This strategy type might be more offensive when it comes to seeking new markets and market opportunities.

f. Non-innovation or traditional strategy: suited for firms which produce standardised products under competitive circumstances that see no reason for product change since they believe the market requires no changes or are not forced by the competition to introduce product changes.

Concerning the link between technical and organisational innovations on one hand and between product and process innovations on the other (Freeman, 1992; Stoneman, 1987), two more types of innovation strategies are possible: innovating firms can follow the strategy of radical product innovation (see Estevez-Abe et al., 2001 from the institutional point of view) and the strategy of radical or incremental process innovation simultaneously. While classifying the anticipated level of firm innovation with respect

2 Note that imitation must be distinguished from copying since the former means legal activity based on the firm's own RED exploiting existing patent documentation while the latter leads to the infringement of patent law. 
to the corresponding innovation strategy, it is observed that the anticipated level of firm innovation should be higher in the case of radical product and process innovation than in the case of incremental innovation since the former is usually linked with greater R\&D efforts and outlays than the latter, at least in corporations where R\&D is planned and performed as a systematic routine (Ilič, 2017). The highest level of firm innovative activity should be expected when combining both product and process innovation since this leads to not only higher RR input but higher R\&D output too (i.e. product and process inventions, useful suggestions for working process improvements etc). Consequently, following empirical evidence, the greater the extent of new product or process radicality in a dynamic environment, the higher the new venture's profits (and rate of return on equity, respectively) and the higher the growth of its market share. The same significant relationship should hold for technological strategy based on intensive rather than incremental product upgrades (Zahra and Bogner, 1999).

\section{Competitive Strategy, Competitiveness and Competitive Advantage}

On the firm level, competitiveness is "the ability to produce the right goods and services of the right quality, at the right price at the right time"; more precisely, it means "meeting customers' needs more efficiently and more effectively than the other firms do" or in general, it is "the ability of an organisation to compete successfully with its commercial rivals" (Balkyte and Tvaronavičiene, 2010: 343). A firm may be said to possess a competitive advantage over its rivals when it enjoys profits that exceed the average for its industry. Porter (1998a, 1998b) identified two basic types of positional competitive advantage: cost advantage and differentiation advantage. The former exists when a firm in an industry (i.e. the cost leader) is able to deliver the same benefits as the competitors but at less cost, while the latter exists when the firm (i.e. a differentiation leader) is able to deliver benefits that exceed those of competing products. Consequently, a competitive advantage enables the firm to create superior value for its customers and superior profits for itself (e.g. through innovation). According to the resource-based view in Porter's model of competitive advantage (see also Grant, 1991), a firm utilises its resources and capabilities to create a competitive advantage that ultimately results in the creation of superior value (Barney, 1991). ${ }^{3}$

In order to develop a competitive advantage, a firm's resources and capabilities should be superior to those of its competitors or else the competitors

3 The firm creates value by performing a series of activities (e.g. RED or human resource management, the activity associated with the recruiting, development and compensation of employees). To achieve a competitive advantage, it must perform one or more value-creating activities in a way that creates more overall value than competitors do. 
simply could replicate (or imitate) the firm's activities and any advantage quickly would disappear. Resources are hence the firm-specific assets useful for creating a cost advantage or differentiation advantage and that few competitors can acquire easily (e.g. patents and trademarks, proprietary know-how, brand equity, goodwill of the firm). Capabilities refer to a firm's ability to effectively utilise its resources. Embedded in the organisational routines, the capabilities are not easily documented as procedures, thus making it difficult for competitors to replicate. Resources and capabilities form distinctive competencies which enable innovation, efficiency, quality and customer responsiveness, all of which can be leveraged to create a (cost or differentiation) competitive advantage (Porter, 1998b).

Porter (2004) identified four generic strategies regarding low cost or product uniqueness on one hand, and broad (industry-wide) or narrow (market segment) target scope on the other. Defined as the ability to compete effectively, competitiveness should be understood as a precondition for a competitive advantage. In other words, investment in the firm's competitiveness (e.g. R\&D outlays) could be understood as the cost of the 'ticket' giving an opportunity to create a competitive advantage in a competitive race.

\section{The CALF model and innovation strategy}

Innovating firms are oriented to either (re)gaining competitive advantage or maintaining competitiveness. In the first case, an offensive type of innovation strategy could be a suitable business solution for achieving this goal, while in the second case a defensive one, thereby depending on external environment characteristics. Thus, in a dynamic or heterogeneous environment a new venture should repeatedly develop and introduce radically new products, whereas those ventures that act as technological followers may have difficulty sustaining a high level of performance over time. On the contrary, in the case of environmental hostility new firms will compete primarily as technological followers (Zahra and Bogner, 1999). Note that according to empirical evidence for moderately high levels of competition enhanced competition in the business environment discourages product innovations but encourages process innovations (Beneito et al., 2014: 306) Moreover, when analysing the dynamics of innovation, offensive and defensive innovation strategies can be considered as mutually intertwined since innovation competition often forces firms into proactive as well as reactive innovation simultaneously. Consequently, the same firm could be posited as an innovation leader in one period and as an innovation follower later, and vice versa (see also Park and Bae, 2004). 
Innovation competition that would imply a firm selects a suitable innovation strategy may be illustrated in the case of a cost-cutting process invention by the cost-advantage leader-follower (CALF) model that relies on the following main assumptions:

a. unlike Etro $(2004)^{4}$, imperfect competition is assumed with high firm rivalry and not extremely high entry barriers, e.g. in a capital-intensive, high-tech, ICT or pharmaceutical industry; very competitive (e.g. contestable) market as in Baumol's (2002) feedback growth model based on intense oligopoly competition where continuous innovation is understood as a 'routine' activity in firms forced by the Schumpeterian innovation competition which - in line with empirical evidence by Beneito et al. (2014) - encourages process innovation;

b. concerning the structure-conduct-performance (SCP) paradigm, conduct (and performance) is in line with the competitive paradigm of patent protection, where the incentive to invent derives from the need to survive in the global competitive market rather than from monopoly profits flowing from patent protection since "patents reduce the level of competition in the industry" (Beneito et al., 2014: 288; this would also be proposed by the traditional monopoly paradigm of patents);

c. the dynamism of the external environment is assumed to encourage new ventures to engage in constant innovation, as well as to patent their innovations and safeguard them against abuses by rivals, with possible positive effects for their performance when they develop a technological strategy as part of a comprehensive strategy to manage that technology as an ongoing resource fitting the competitive environment (Zahra and Bogner, 1999);

d. a patented cost-reduction process innovation (which can be either pioneer, major or incremental, minor) initially introduced by the first inventor, i.e. the representative innovating firm (A), i.e. the innovation leader having - in accordance with Freeman and Soete (1997) - an offensive innovation strategy;

e. all or at least the majority of firms in an industry are assumed to be "bimodal learners" or "unbounded innovators", i.e. learning firms adept at both knowledge exploration and exploitation, for example in the case of an imitation innovation strategy (Bierly and Daly, 2002; Zack, 2002);

f. following Porter (1998a, 1998b, 2004) as well as Freeman and Soete (1997), all or at least the majority of rival firms in an industry are assumed to be active competitive advantage (CA) seekers, i.e. innovation followers, applying defensive/reactive innovation or an imitation strategy

4 Etro (2004) introduced a patent race model assuming the persistent monopoly of the incumbent firm, i.e. the innovation leader. 
and - according to the competitive nature of patent protection (Ilič and Pretnar, 2004) - competing to invent a better technological process in order to 'catch' the first inventor and obtain a relative CA; and

g. constant returns and, therefore, constant marginal costs (MC), competitive firms (rivals) with (at least initially) the same cost structure and similar potential for R\&D (e.g. capital equipment, financial and human resources etc.).

Suppose that firm A suddenly introduces its own cost-reduction process invention, which initially lowers its marginal costs for $\triangle \mathrm{MC}$ and gives A starting absolute CA per unit $(\mathrm{CA}=\Delta \mathrm{MC})$, which results in the same increase in A's profit per unit $(\pi)$, all else equal. Moreover, at any time $(t)$, given the firm size, quantity (q) and price (p), the initial size of A's net CA is then: CA ( $\mathrm{t})=$ $\triangle M C(t)$ - RDC, where RDC is the size of initial R\&D costs per unit (assumed as fixed and sunk as well as a constant amount per unit, independent of $\mathrm{t}$ ). On the other side of the coin and following Porter (1998), CA in our model should be defined exactly as profit increment per unit:

$\mathrm{CA}(\mathrm{t})=\Delta \pi(\mathrm{t})$, ceteris paribus

Thus, the CA function of A can be defined as being dependent on $t$ as follows:

$$
C A(t)=\left\{\begin{array}{l}
\Delta M C-R D C=\text { const, }{ }^{5} \text { if } 0 \leq t \leq t_{C} \\
\Delta M C \cdot e^{-\lambda \cdot(t-t c)}-R D C \text {, thereafter }
\end{array}\right.
$$

where $\mathrm{t}_{\mathrm{c}}$ denotes a 'reaction' time (or gap) in which the competing innovation followers respond to A with their competitive cost-cutting inventions which narrow the first inventor's CA 'wedge'. This occurs because some time is needed for the competing firms to attain and study information about the patented process in patent documentation as well as to engage own R\&D resources and to invent a competitive process invention on that basis (e.g. by imitation). Assuming a gradual reduction of A's absolute CA after $\mathrm{t}_{\mathrm{c}}$, transforming it into relative CA of A over the rivals $\mathrm{CA}(\mathrm{t})$ is falling in time following, for example, an exponential trajectory (i.e. $\mathrm{e}^{-\lambda(\mathrm{t}-\mathrm{tc})}$ in our case, similar to a learning curve), denoted by the solid curve shown in Figure 2.

Parameter $\lambda$ is composed of two variables. The first $(\delta)$ measures the impact of the technology obsolescence rate, indicating the speed and intensity of a rival process invention (applying either offensive or defensive innovation/imitation strategy) which depends on the industry concentration rate $(\eta)$, while the second measures the rate of rival cost reductions

5 Constant, independent of time due to the initial absolute cost advantage of A over its competing firms (i.e. a "winner-takes-all" situation if $O \leq t \leq t$ ). 
$(\omega)$. Both affect A's CA schedule at any time after tc: $\lambda(t)=\lambda(\delta(\eta), \omega), \lambda>0 .{ }^{6}$ Expressed more clearly, rival cost reductions aimed at cutting A's relative $\mathrm{CA}$ in order to increase the cost competitiveness of a rival firm (even leading to a possible relative CA over $A$ ) when $t>t_{c}$, derive from certain activities (either alternative or additional activities complementary to process invention or R\&D) processed by the competing firms. Thus, the higher the $\lambda$, all else equal, the lower A's CA over competing firms. The lower the entry barriers, the lower the $\eta$, the higher the $\delta$ (since more intense technological rivalry and, thus, faster technological obsolescence can be expected as $\eta$ falls to some degree) and the higher the $\lambda$, making the CA (t) schedule steeper after tc (the dash dotted curve in Figure 2). The higher the responsive (additional) cost reductions of rival firms different from the cost-cutting process inventing, the higher the $\omega$ and the $\lambda$, and the steeper the CA $(\mathrm{t})$ schedule. One possible alternative response could be employee dismissals. They may be viewed as a kind of competitive 'strategy' that is significant for many employers in Slovenia and other catching-up economies in Eastern and South-east Europe as well as a consequence of firm restructuring, often combined with work intensification and used over the last 15 years as a way to increase firm productivity and competitiveness or even obtain competitive advantage. Others for example could be a technological licence or the purchasing of know-how as well as work motivation viewed as increasing firm performance (Steers et al., 2004), education, learning-by-doing or on-the-job training as the complementary activities which - deriving from human capital theory (Becker, 1964; Schultz, 1971) - raise the quantity and quality of human capital and thereby increase marginal productivity (or decrease marginal costs) as well as wages.

The long-dashed curve in Figure 2 indicates a special case of a very competitive setting where a rival imitation occurs (almost) immediately, pushing the reaction time lag $\left(\mathrm{t}_{\mathrm{c}}\right)$ towards 0 , thus instantly transforming A's absolute CA into a relative one. ${ }^{7}$

At time $t_{0}$, ceteris paribus, A's relative CA falls to 0 (the solid curve) since rival firms have reduced it entirely, and it then becomes even negative transforming into A's relative cost disadvantage (CDA). Moreover, t0 denotes the last possible, 'critical' time for firm A to introduce next process invention, ${ }^{8}$

6 The extreme situation when $=0$ means the absence of rival innovation competition $(\delta=0$, e.g. in a persistent monopoly if $\eta=1$ or in perfect competition if $\eta=0$ as well as in the case of innovatively inactive rivals) and the absence of additional cost reductions $(\omega=0)$. In this case, the first inventor preserves the initial absolute CA in time.

7 When a process invention is unpatented, immediate free riding is a possible consequence so that the reaction-time lag disappears and rivals can neutralise A's absolute $C A$, instantly pushing it towards $O$.

8 However, it is possible for $A$ to introduce a new process invention before $t O$. For simplicity, this case is omitted from Figure 3 . 
Figure 2: THE CA FUNCTION OF THE FIRST INVENTOR (FIRM A) AND RIVAL RESPONSE IN TIME

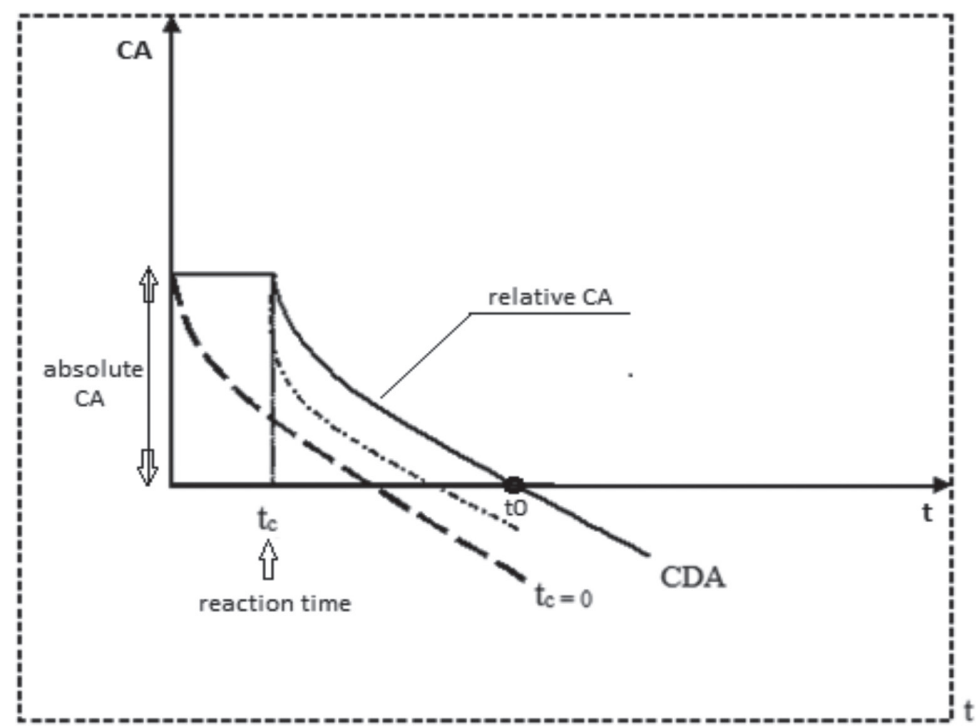

Source: own analysis.

developed in period $t_{0}-t_{c}$ (defining the length of A's process $R \& D$ cycle in Figure 3) in order to regain its relative CA over the competing firms. The greater the process innovation competition, all else equal, the faster the rival reactions, shortening A's relative CA and speeding up its R\&D in period $t_{0}$ $\mathrm{t}_{\mathrm{c}}$ (as $\mathrm{t}_{0}$ approaches $\mathrm{t}_{\mathrm{c}}$ ).

The process then repeats. However, A can also regain absolute CA for a short time period after $\mathrm{t}_{0}$, whereby

$\mathrm{t}_{0}=\mathrm{t}_{\mathrm{c}}+(\ln (\mathrm{RDC} / \Delta \mathrm{MC})) / \lambda$ initially, and $\mathrm{t}_{0}{ }^{\prime}=\mathrm{t}_{\mathrm{c}}{ }^{\prime}+\left(\ln \left(\mathrm{RDC}^{\prime} / \Delta \mathrm{MC} \mathrm{C}^{\prime}\right)\right) / \lambda$ in the second R\&D circle, respectively (see Figure 2 ), assuming a realistic, conventional case where $\mathrm{RDC}<\Delta \mathrm{MC}^{9}$ such that $\ln (\mathrm{RDC} / \Delta \mathrm{MC})>0$. If tc approaches 0 (the special case of a very fast rival imitation), then

$\mathrm{CA}(\mathrm{t})=\Delta \mathrm{MC} \cdot \mathrm{e}^{-\lambda \cdot \mathrm{t}}-\mathrm{RDC}$,

and both the length of A's critical time as well as its process R\&D cycle while responding to competitors are shortened to $t_{0}=(\ln (R D C / \Delta M C)) / \lambda$. This result is quite different from that of Etro's (2004) model of an innovation leader with the persistence of a monopoly. This is also due to the greater intensity and speed of Schumpeterian competition through permanent

9 In fact, $t_{O}=t_{c}-(\ln (R D C / \triangle M C)) /$ but if $R D C<\Delta M C$ then $\ln (R D C / \triangle M C)<O$ and $t_{0}=t_{c}+$ $(\ln (R D C / \triangle M C)) /$ consequently. If $R D C>\triangle M C$, the introduction of a process invention is, of course, irrational for this firm from the CA aspect. 
process invention that is otherwise significant for knowledge-based organisations and their business environment too.

Figure 3: REGAINING A'S ABSOLUTE AND RELATIVE CA AFTER A CRITICAL TIME IN THE CALF MODEL

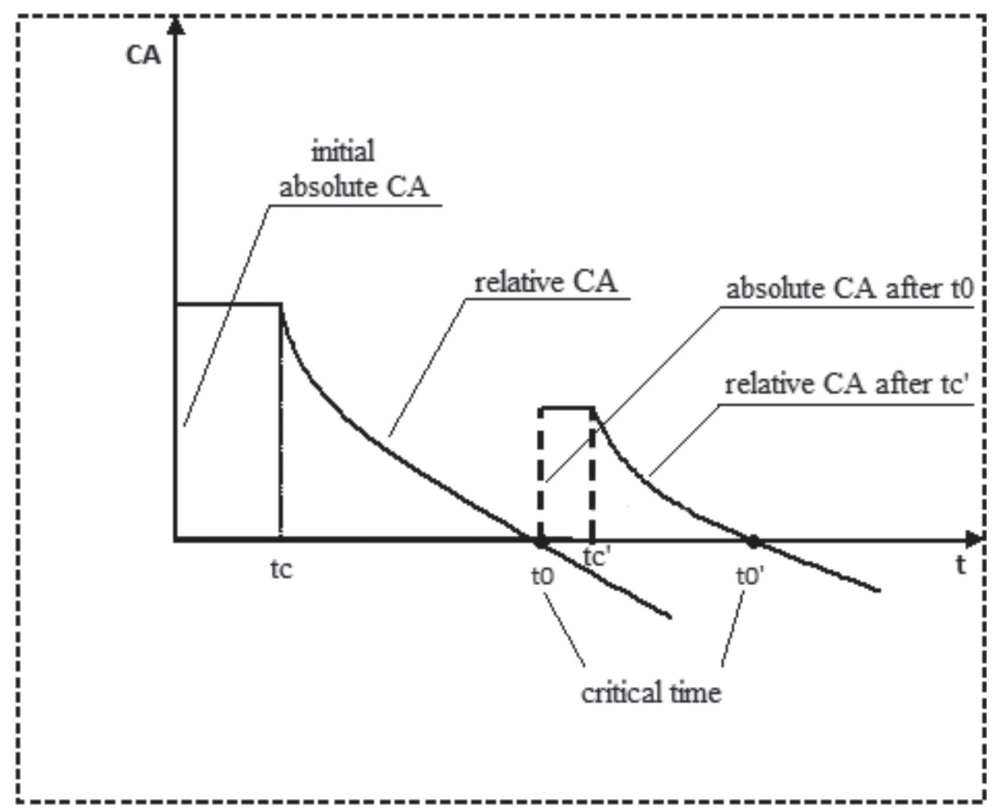

Source: Own analysis.

\section{Discussion}

Considering Porter's (1998a, 1998b) typology of competitive strategies (cf. Valdani and Arbore, 2013) of firms and industries, innovation provides an affordable cost and competitive advantage over competitors, allowing the assumption that the most innovative firms develop an active strategy of (incremental) process innovation which is complementary to the strategy of product innovation, as shown by Park and Bae (2004). We assumed that innovation competition is the underlying basis explaining the competitive theory of patents (Ilič and Pretnar, 2004). Noting the initial research question and taking the findings of our analysis into account, it may be stated that the CALF model offers a possible alternative mechanism for economically describing the dynamics of the technological rivalry among competitors in an oligopolistic market driven by Schumpeterian innovation competition (Baumol, 2002). Here, innovation appears as a result of a highly-skilled 
workforce trained with specific skills or knowledge. This requires the efficient adaptation of human resource management, a suitable knowledge strategy and proper human resource management practices, e.g. education, stimulating work motivation activities (Steers et al., 2004) as well as a rewards system (Bierly and Daly, 2002) etc., aimed at promoting continuous innovation in innovative firms.

Since firms in crises are also involved in international price competition pressures to reduce costs and prices, we cannot neglect the analysis of (incremental or radical) process innovations as a specific innovation strategy, even though some authors (e.g. Estevez-Abe et al., 2001) do not mention it. On the other hand and proceeding from their argument, the strategy of incremental process (or product) innovation for maintaining the competitiveness of the Slovenian economy as a coordinated market or catching-up economy seems a more appropriate choice of strategy for radical product and process innovation. This may occur as either a substitute, (especially) to complement or as an element of the strategies mentioned above, especially in diversified production; and when product innovation markets are in place it reaches maturity and begins to compete with the prices of existing products. Process innovation as a result of rivalry in the CALF model can amount to product innovation, but can also be an alternative to the current practice of work intensification in Slovenian firms (see Stanojević, 2006), also suitable for catching-up economies.

\section{Conclusion}

The main purpose of this article has been to provide a global framework for venture and firm strategies in pursuing different business opportunities. The adoption and application of a neo-Schumpeterian perspective in the two decades between 1990 and 2010 has led to a proliferation of approaches that place the innovation system at the centre of analysis (Wolfe and Vatne, 2011). This study suggests a competitive strategy to seek attractive business opportunities for ventures and firms from a global perspective and proposes an innovation strategy for ventures and firms in catching-up economies, developing countries or ones facing a crisis. Further, the great focus on firms in the developed world means researchers have paid little attention to the competitive strategies of ventures and firms in developing countries.

Although this study is conceptual in nature, it also has certain theoretical and practical implications and limitations (that should be noted while considering the initial research question). First, it is based on several more or less realistic assumptions and model simplifications. Second, with these limits, the CALF model explains strategic firm behaviour (in order to achieve or 
at least maintain a cost advantage) quite realistically with respect to process innovations, while the case of product innovations is abstracted here. Here, the CALF model calls for a theoretical and empirical extension - perhaps by forming an analogous 'product differentiation-advantage leader-follower model' (PDALF model) as 'a conceptual twin' of the former and, finally, an adequate integration of both. In any case, the idea of introducing a PDALF model deserves detailed investigation in future research while the CALF model requires further (empirical) examination. Third, by taking some Time-sensitive environmental and behavioural factors into account, our modelling approach moves being comparative static to dynamic. Therefore, in order to improve the CALF model's dynamic character we need to explore and develop more refined research models. In addition, empirical studies should be done with samples from diverse settings.

Future research could focus on developing more extensive theories regarding new venture strategy and growth. The empirical test of strategic types and performance in the specific contexts of catching-up economies will help explain which competitive and growth strategies are attractive for ventures and firms in developing countries. Finally, such a test could also serve as a starting point for comparing (and examining) differences among new venture and industry strategies among countries.

Although this conceptual study deserves further theoretical research as well as more empirical investigation in different settings to enhance its testing, it already holds some managerial implications. In particular, the competitive strategy framework set out in this article can help ventures and firms select the right business and suitable human resource strategies/practices among different business opportunity sets in a given situation in order to foster continuous innovation on the firm and industry level.

\section{BIBLIOGRAPHY}

Adler, Paul Simon (1989): Technology Strategy: A Guide to the Literature. Research on Technological Innovation, Management and Policy 4: 25-151. Accessible at https://www.researchgate.net/profile/Paul_Adler/publication /284931701_Technology_strategy_A_guide_to_the_literature/links/5a5cd /293a6fdcc68fa96e 407/Technology-strategy-A-guide-to-the-literature.pdf?/ origin=publication_detail, 30.7.2020.

Argyris, Chris and Donald A. Schön (1978): Organizational Learning: A Theory of Action Perspective. Reading, Mass: Addison Wesley.

Armstrong, Michael (2006): A Handbook of Human Resource Management Practice. 10th ed. London: Kogan Page.

Afuah, Allan (2003): Innovation Management. Oxford: Oxford University Press.

Akman, Gülşen and Cengiz Yilmaz (2008): Innovative Capability, Innovation Strategy and Market Orientation: An Empirical Analysis in Turkish Software Industry. International Journal of Innovation Management 1 (12): 69-111. 
Balkyte, Audrone and Manuela Tvaronavičiene (2010): Perception of Competitiveness in the Context of Sustainable Development: Facets of Sustainable Competitiveness. Journal of Business Economics and Management 2 (11): 341-365. Accessible at https://www.researchgate.net/profile//Manuela _Tvaronaviciene/publication/247904640_Perception_of_competitiveness_in_ the_context_of_sustainable_development_Facets_of_sustainable_competitiveness/links/00b49534c303c6adb0000000/Perception-of-competitiveness-inthe-context-of-sustainable-development-Facets-of-sustainable-competitiveness. pdf?origin=publication_detail, 30. 7. 2020.

Barney, Jay (1986): Strategic Factors Markets: Expectations, Luck and Business Strategies. Management Science 32: 1231-1241.

Barney, Jay (1991): Firm Resources and Sustained Competitive Advantage. Journal of Management 17 (1): 99-120. Accessible at https://josephmahoney.web.illinois.edu/BA545_Fall\%202019/Barney\%20(1991).pdf, 30. 7. 2020.

Baumol, William (2002): The Free-Market Innovation Machine. Princeton: Princeton University Press.

Becker, Gary S. (1964): Human Capital: A Theoretical and Empirical Analysis, with Special Reference to Education. Third edition. Chicago: The University of Chicago Press.

Beneito, Pilar, Maria Engracia Rochina-Barrachina and Amparo Sanchis (2014): Patents, Competition, and Firms' Innovation Incentives. Industry and Innovation 21 (4): 285-309.

Bierly, Paul E. and Paul Daly (2002): Aligning Human Resource Management Practices and Knowledge Strategies. In Chun Wei Choo and Nick Bontis (eds), The Strategic Management of Intellectual Capital and Organizational Knowledge, 277-295. Oxford: Oxford University Press.

Borden, Neil H. (1964): The Concept of the Marketing Mix. Journal of Advertising Research June: 7-12. Accessible at http://www.guillaumenicaise.com/wp-content/uploads/2013/10/Borden-1984_The-concept-of-marketing-mix.pdf, 30. 7. 2020.

Brandenburger, Adam M. and Berry J. Nalebuff (1996): Co-opetition. New York: Doubleday.

Cho, Dong Sung, Dong Jae Kim and Dong Kee Rhee (1998): Latecomer Strategies: Evidence from the Semiconductor Industry in Japan and Korea. Organization Science 9: 489-505.

Covin, Jeffrey G. and Dennis P. Slevin (1991): A Conceptual Model of Entrepreneurship as Firm Behaviour. Entrepreneurship Theory Practice (Fall): 7-25.

Covin, Jeffrey G., Dennis P. Slevin and Michael B. Heeley (1999): Pioneers and Followers: Competitive Tactics, Environments, and Firm Growth. Journal of Business Venturing 15: 175-210.

Contractor, Farok J. and Peter Lorange (1988): Cooperative Strategies in International Business. Boston: Lexington Books.

Dagnino, Giovanni Battista and Elena Rocco (2009): Coopetition Strategy: Theory, Experiments and Case. Oxon: Routledge. 
Dodgson, Mark and David Gann (2010): Innovation: A Very Short Introduction. Oxford: Oxford University Press.

Estevez-Abe, Margarita, Torben Iversen and David Soskice (2001): Social Protection and the Formation of Skills: A Reinterpretation of the Welfare State. In Peter A. Hall and David Soskice (eds.), Varieties of Capitalism, The Institutional Foundations of Comparative Advantage, 145-183. Oxford: Oxford University Press.

Etro, Federico (2004): Innovation by Leaders. The Economic Journal 114 April: 281-303.

Freeman, Christopher (1992): The Economics of Hope: Essays on Technological change, Economic Growth and the Environment. London: Pinter.

Freeman, Christopher and Luc Soete (1997): The Economic of Industrial Innovation. Third edition. London: Pinter.

Gandellini, Giorgio, Alberto Pezzi, and Daniela Venanzi (2012): Strategy for Action-I. The Logic and Context of Strategic Management. Milan, Heidelberg: Springer.

Gnyawali, Devi R. and Ravindranath Madhavan (2001): Cooperative Networks and Competitive Dynamics: A Structural Embeddedness Perspective. Academy of Management Review 26 (3): 431-445.

Gagné, Marylène and Edward L. Deci (2005): Self-determination Theory and Work Motivation. Journal of Organizational Behavior 26: 331-362.

Gimbert, Xavier (2011): Think Strategically. Macmillan Publishers Limited. London: Palgrave Macmillan.

Grant, Robert M. (1991): The Resource-Based Theory of Competitive Advantage: Implications for Strategy Formulation. In Michael Zack (ed.), Knowledge and Strategy, 3-23. Boston: Butterworth Heinemann.

Håkansson, Håkan and Claes Ostberg (1975): Industrial Marketing: An Organizational Problem. Industrial Marketing Management 4: 113-123.

Habbershon, Timothy G. and Margaret L. Williams (1999): A Resource-Based Framework for Assessing the Strategic Advantages of Family Firms. Family Business Review 12 (1): 1-22.

Hamel, Gary, Yves Doz and Coimbatore Krishnarao Prahalad (1989): Collaborate with Your Competitors and Win. Harvard Business Review 67 (1): 133-139.

Han, Jin K., Namwoon Kim and Rajendra Srivastava (1998): Marketing Orientation and Performance: Is Innovation a Missing Link? Journal of Marketing (62) October: $30-45$.

Håkansson, Håkan and Ivan Snehota (2006): No Business Is An Island: The Network Concept of Business Strategy. Scandinavian Journal of Management (22): 256 270.

Hellriegel, Don, Susan E. Jackson and John W. Slocum (1999): Management. Eighth edition. Cincinnati: South-Western College Publishing.

Hurley, Robert F. and Thomas G. Hult (1998): Innovation, Market Orientation and Organizational Learning: An Integration and Empirical Examination. Journal of Marketing (62): 42-54. 
Ilič, Branko (2017): Nagrajevanje kot vzvod spodbujanja inovativnosti slovenskih organizacij v (post) kriznem obdobju. In Andrej Kohont and Miroslav Stanojević (eds.), Razpotja in prelomi: spremembe na področju menedžmenta človeških virov v Sloveniji, (Knjižna zbirka Ost, 15), 257-279. Ljubljana: Fakulteta za družbene vede, Založba FDV.

Ilič, Branko and Bojan Pretnar (2004): The Economic Notion of the Incentive to Invent in the Legal Perspective of Patent Protection. Economic and Business Review 4 (6) December: 275-295.

Kessler, Eric H. and Alok K. Chakrabarti (1996): Innovation Speed: A Conceptual Model of Context, Antecedents, and Outcomes. Academy of Management Review 21 (4): 1143-1191.

Lado, Augustine A., Nancy G. Boyd and Susan C. Hanlon (1997): Competition, Cooperation, and the Search for Economic Rents: A Syncretic Model. Academy of Management Review 22 (1): 110-141.

Lumpkin, Tom G. and Gregory G. Dess (1996): Clarifying the Entrepreneurial Orientation Construct and Linking It to Performance. Academy of Management Review 21: 135-172.

Lundvall, Bengt-Åke (1992): Introduction. In Bengt-Åke Lundvall (ed.), National Systems of Innovation: Towards a Theory of Innovation and Interactive Learning, 1-22. London: Pinter Publishers.

Mathews, John A. (2002): A Resource-based View of Schumpeterian Economic Dynamics. Journal of Evolutionary Economics 1 (12): 29-54.

Martin, Roderick (2008): Post-socialist Segmented Capitalism: The Case of Hungary. Developing Business Systems Theory. Human Relations 61 (1): 131-159.

Miles, Raymond E., Charles C. Snow, Alan D. Meyer, Henry. J. Coleman Jr. (1978): Organizational Strategy, Structure, and Process. The Academy of Management Review 3 (3): 546-562.

Ohmae, Kenichi (1982): The Mind of the Strategist: The Art of Japanese Business. New York: McGraw-Hill.

Prahalad, Coimbatore Krishnarao and Gary Hamel (1990): The Core Competence of the Corporation. Harvard Business Review, May-June Issue: 235-256.

Park, Sangmoon and Zong-Tae Bae (2004): New Venture Strategies in a Developing Country: Identifying a Typology and Examining Growth Patterns through Case Studies. Journal of Business Venturing 19: 81-105.

Porter, Michael E. (1980): Competitive Strategy. Techniques for Analyzing Industries and Competitors. New York: Free Press.

Porter, Michael E. (1983): The Technological Dimension of Competitive Strategy. In Richard S. Rosenbloom (ed.), Research on Technological Innovation, Management and Policy, 1-33. Greenwich, CT: JAI Press.

Porter, Michael E. (1985): Competitive Advantage: Creating and Sustaining Superior Performance. New York: Free Press.

Porter, Michael E. (1998a): The Competitive Advantage of Nations: With a New Introduction. New York: The Free Press.

Porter, Michael E. (1998b): Competitive Advantage: Creating and Sustaining Superior Performance: With a New Introduction. New York: The Free Press. 
Porter, Michael E. (2004): Competitive Strategy: Techniques for Analysing Industries and Competitors: With a New Introduction. New York: The Free Press.

Richardson, Gary B. (1972): The Organisation of Industry. Economic Journal 82 (327): 883-896.

Schultz, Theodore W. (1971): Investment in Human Capital: The Role of Education and of Research. New York: Free Press.

Schumpeter, Joseph Alois (1939): Business Cycles. A Theoretical, Historical and Statistical Analysis of the Capitalist Process. New York: McGraw Hill Book Company.

Schumpeter, Joseph Alois (1951): The Theory of Economic Development. Cambridge: Harvard.

Schumpeter, Joseph Alois (1934, 2004): The Theory of Economic Development: An Inquiry into Profits, Capital, Credit, Interest, and the Business Cycle. Tenth printing 2004. New Brunswick, London: Transaction Publishers.

Shane, Scott A. and Sankaran Venkataraman (2000): The Promise of Entrepreneurship as a Field of Research. Academy of Management Review 25: 217-226.

Stanojević, Miroslav (2006): Mobilising Human Resources to Improve Work Intensity. In Ivan Svetlik and Branko Ilič (eds.), HRM's Contribution to Hard Work: A Comparative Analysis of Human Resource Management, 157-181. Bern [etc.]: P. Lang.

Steers, Richard M., Richard T. Mowday and Debra L. Shapiro (2004): Introduction to Special Topic Forum the Future of Work Motivation Theory. Academy of Management Review 3 (29): 379-387.

Stevenson, Howard H. and Carlos J. Jarillo (1990): A Paradigm of Entrepreneurship: Entrepreneurial Management. Strategic Management Journal, 11 (Special Issue, Summer 1990): 17-27.

Stoneman, Paul (1987): The Economic Analysis of Technology Policy. Oxford: Clarendon Press.

Teece, David J. (1990): Capturing Value through Corporate Technology Strategies. In L. M. Ducharme Science, Technology and Free Trade (ed.), 69-84. London: Pinter Publishers.

Teece, David J. (2010): Business Models, Business Strategy and Innovation. Long Range Planning 43: 172-194.

Utterback, James M. (1994): Mastering the Dynamics of Innovation. Boston, MA. Harvard Business School Press.

Vadi, Maaja and Harald Lepisk (2012): Creativity and Learning in Innovation Processes. In Elias G. G. Carayannis, Urmas Varblane and Tönu Roolaht (eds.), Innovation Systems in Small Catching-Up Economies: New Perspectives on Practice and Policy, 79-96. New York: Springer.

Valdani, Enrico and Alessandro Arbore (2013): Competitive Strategies. Managing the Present, Imagining the Future. New York: Palgrave Macmillan.

Wernerfelt, Birger (1995): A Resource-based View of the Firm: Ten Years After. Strategic Management Journal 16 (3): 171-174.

Williamson, Oliver E. (1975): Markets and Hierarchies: Analysis and Antitrust Implications. New York: Free Press. 
Williamson, Oliver E. (1985): The Economic Institutions of Capitalism. New York: Free Press.

Wolfe, David and Eirik Vatne (2011): Neo-Schumpeterian Perspectives on Innovation and Growth. In Philip Cooke, Bjørn Asheim, Ron Boschma, Ron Martin, Dafna Schwartz and Franz Tödtling (eds.), Handbook of Regional Innovation and Growth, 43-53. Cheltenham: Edward Elgar.

Zahra, Shaker A. (1993): A Conceptual Model of Entrepreneurship as Firm Behavior: A Critique and Extension. Entrepreneurship Theory and Practice 17 (4): 5-21.

Zahra, Shaker A. (1996): Technology Strategy and Financial Performance: Examining the Moderating Role of the Firm's Competitive Environment. Journal of Business Venturing 11: 189-219.

Zahra, Shaker A. and William C. Bogner (1999): Technology Strategy and Software New Ventures' Performance: Exploring the Moderating Effect of the Competitive Environment. Journal of Business Venturing 15 (2): 135-173. 